\title{
Minority Regional Tourism Development and the Refactoring of Minority Culture
}

\author{
Xiufang Li1,2 \\ ${ }^{1}$ Research Institute of Education and Psychology of Southwest Ethnic Groups, Southwest University, Chongqing, \\ China \\ ${ }^{2}$ Department of Education, Dali University, Dali, China \\ Email: baicai0616@163.com
}

Received 21 August 2015; accepted 14 September 2015; published 17 September 2015

Copyright (C) 2015 by author and Scientific Research Publishing Inc.

This work is licensed under the Creative Commons Attribution International License (CC BY).

http://creativecommons.org/licenses/by/4.0/

(c) (i) Open Access

\begin{abstract}
This paper discusses the refactoring of minority culture in the period of social transformation in China, and the tourism development boom in the minority area. First of all, based on the field survey of the town called $W$, we find that the social life and cultural structure of $W$ town are changing with the prosperity of the tourism economy. There are three main performances: 1) the fragmentation of Bai culture, 2) the tourism symbolization of Bai culture, and 3) the opening of the Bai culture space. In the end, the essence of cultural refactoring is analyzed from the perspective of theory.
\end{abstract}

\section{Keywords}

Minority Culture, Refactoring, Fragmentation, Tourism, Symbolization

\section{Introduction}

Cultural change is a subject of concern of anthropology. In the process of globalization, modern China has a dramatic change from the way of life to the way of thinking. Anthropologists believe that cultural change is a normal phenomenon of culture. The stability and equilibrium of culture are relative, but cultural change is absolute. According to the scholars' study on the cultural changes, there were some theories such as evolutionary theory, communication theory, acculturation, re-interpretation and so on. Generally, one of the reasons for the change of culture is internal, which is caused by the change of the society; the other one is external, which is caused by the changes of the natural environment and the social and cultural environment (Y. H. Lin, 1997) [1]. Tourism development belongs to external factors, and it is a comprehensive external factor. Some scholars believe that the local society in the development of minority tourism has become the intersection point of the "cultural change” in the global and local perspective. It reflects the interaction of tourism development and econom- 
ics, politics, culture and power (J. X. Sun \& J. Su, 2011) [2]. Many Chinese cultural anthropology researchers hold a diverse perspective on the causes and forms of cultural changes.

At the beginning of the twentieth century, Chinese scholars applied western culture change theory to Chinese native research. The initial stage was mainly to study Han culture change, and then concerned about the cultural changes of ethnic minorities. In recent years, scholars have begun to take their own thinking as the new blood of the theory of cultural change, and pay more attention to the initiative and creativity of cultural subjects. Guo Ling believed that the prosperity of tourism is a phenomenon, which hides a deeper social life and cultural structure changes. Government, tourists, aboriginal, foreign investors in the tourism industry are as a link to form a new pattern of tourism spatial relations. In the process of the formation of tourism space, the behavior of the people changes the way of production and life, and constantly breaks the original relatively closed social space, and the minority culture to complete self renewal and transcendence in the way of "reproduction" (L. Guo \& N. D. Yang, 2014) [3]. Yan Mo used the term "refactoring". Refactoring is a term used in the field of computing, when applied in the field of cultural anthropology; its first prerequisite is the semantics, in the premise of not changing the observable behavior to improve its internal structure, and reconstruction is a more cautious, more conservative process, as well as a "new life" through the reconstruction of the harvest. This paper is more inclined to use the word refactoring. We believe that the reconstruction of the minority culture is a creative adjustment by people in the process of cultural transformation, and is a recreation by the state, the government and the minority.

\section{Research Methodology}

\subsection{Research Object}

Dali W town is located in the northwest of Yunnan Province, $67 \mathrm{~km}$ from the city of Dali, before the tourism development, the Bai culture factor in $\mathrm{W}$ town is easily defined. $\mathrm{W}$ town has beautiful natural scenery, known as "the best Cang-er scenery is in W town", Bai fishing and hunting as well as farming culture, is closed, simple and plain. W town is a typical minority village, with a rich cultural resource of minority. In the course of historical development, the minority culture in the $\mathrm{W}$ town has a relatively distinct stage character. The first stage is the traditional view of the $\mathrm{W}$ town (before 1996). The local production method is mainly based on small planting agriculture and mountainous animal husbandry and extensive freshwater fishery. Because of the traffic block, the foreign economic and communication activities are less, and the culture of the Bai nationality is relatively strong, which forms a relatively simple cultural space. The second stage is the autonomous development period of the folk tourism (1996-2006). In 1996 Eryuan county government, W township government and Dali Economic Development Corporation cooperated; they built the Jinsuo island into the "Nanzhao style island" as a tourist spot of $\mathrm{W}$ town. This initiative drives the minorities to join the tourism industry. However, the tourism industry in this period has not changed the daily lives of most people in the $\mathrm{W}$ town. The third stage is the market leading tourism development period (2006 so far). Painter Zhao Qing who was born in W town vigorously promote their hometown. The famous dancer Yang Liping settled in the town, celebrity effect makes the town reputation. Tourism has gradually to be a pillar industry in $\mathrm{W}$ town. In the past three years, the town of $\mathrm{W}$ from an unknown college became an important tourist destination in the east coast of Erhai.

\subsection{Research Method}

This research chose the qualitative analysis method as the main research method, uses the participation observation and the interview as main techniques. The purpose of the participation observation is to obtain a more specific understanding of the local culture and to understand the life the local people. The purpose of the interview is to get a deeper understanding of the local culture and to understand the local people's psychological activities and ideas. During July 2015 to May 2014, the researchers conducted a field survey of W Town, in order to formal interviews. I interviewed a total of 70 people, including 3 government staff, 22 local residents, tourists 30 people, 15 foreign investors, and from January 2015 to March to enter the local community, launched a participatory observation.

\section{Findings}

Based on the above research methods, we have obtained a wealth of research materials. We find that the social 
life and cultural structure of $\mathrm{W}$ town are changing with the prosperity of the tourism economy. There are three main performances: first is the fragmentation of Bai culture, second is the tourism symbolization of Bai culture, third is the opening of the Bai culture space.

\subsection{The Fragmentation of Bai Culture}

The original meaning of "fragmentation" is "to divide the whole thing into a lot of parts". This is a vivid expression of the current communication context. Remove culture from the soil of its existence, and then deconstruct, diversion, mosaic it. So the fragmentation of culture is happening. With the development of information technology, cultural fragmentation is almost a universal cultural logic in the era of globalization. We can also regard fragmentation as a kind of diversification, which is a kind of negation to the unity and integrity.

In order to cater to the diverse needs of tourists, government and investors often display the various fragments of national culture but not the whole, so it is very difficult to fully reflect the essence of the national culture. For example, "The three cup of tea" is a solemn tea ceremony "of the Bai people in Dali”. Three kinds of taste of tea represents three different life perception, bitter tea represents the hardships of entrepreneurship, sweet tea means the Sweet of success, mixed taste of tea means a reviewing of life. The Tourism Bureau selected out the "The three cup of tea” from the whole of the Bai culture, they capture the simplicity of tea sets and the impressive performance of the process, make it to be a string of visual symbols which is embedded in a stage performance. In their eyes, entertainment and novelty are more important than the culture itself. People are no longer concerned about the expression and thinking of life in the process of tea drinking and tea making. Even the taste of tea and the quality is no longer concerned. Today, with the population of self media, fragmented writing is welcomed by tourists. They are more willing to browse assorted information on the local web page, patient and meticulous communication and voluminous literature in their eyes is incredible.

Before the development of tourism, the material culture of $\mathrm{W}$ town is influenced by historical and natural conditions, which not only meets the needs of the people's production and life, but also reflects the concept of the harmony between the people and the nature. After the development of tourism, the production and life style of ethnic minorities have a fundamental change. Tourism replacing traditional agriculture becomes a pillar industry in the $\mathrm{W}$ town. Tourism revenue has become the main economic income. Only a few of the traditional crafts also produce local specialties and tourist souvenirs to obtain profits, in fact, is also added to the tide of Tourism. The traditional architecture has gradually lost its ethnic characteristics. Bai People's housing construction materials, the structure and function has undergone tremendous changes. Steel and cement substitute for wood and stone as the main building materials. The traditional layout of the house no longer exists. The penthouse is used as audio-visual room, the main room is used as a tourist reception hall. In recent years, most of the new houses with full of urban architectural elements that is described as petty bourgeoisie, large bay windows and glass doors, exquisite window, elegant flower, and pop music. The settlement of $\mathrm{W}$ town has changed too. Before the tourism development, farm road connected Bai people's old housed which located on the lakeside of Erhai and the hill-foot of Cangshan, and form a quiet and harmonious village. Lakeside villagers began to rent out their house, the tenant will be converted old houses into hotels with its own characteristics. Commercial street was built on the side of the road, the large parking lot and recreation area occupy the public space of the villagers.

\subsection{The Tourism Symbolization of Bai Culture}

Symbolization of minority culture in the tourism scene performance as the symbolization of tourist landscape. It includes the stage performance and the industrial development of the manufacturing of symbolic tourism products and the symbolic landscape sign system. Tourism product is a kind of art processing, refining and re interpretation of the minority culture. Tourism landscape symbol is the result of the commercialization of the minority culture resources, and the form of the regeneration of the minority culture (R. Gui, 2013) [4].

$\mathrm{W}$ town provide rich cultural experience to tourists in the way of restoration of historical relics, traditional business atmosphere construction, and the traditional folk performances. The symbolic production of material cultural heritage depends on material entities such as architecture, statues, etc., such as Hongshan temple, Zhengjue temple, Yang Liping Sun Palace and ancient town street, the ancient stage, Kui pavilion, Yubo pavilion, Ancestral hall, Master temple, Traditional courtyard, Couplets, and so on. Symbolization of the intangible cultural heritage include traditional folk experience and traditional handicraft exhibitions. For example, Ancient 
Nanzhao Dongjing music, Marriage custom, Festival celebration, Bai Opera, Bai’s Cheese making, Cormorant fishing. Bai traditional dance art is a typical and special cultural symbols, it has a distinct feature, expressive force and Aesthetic. Rattle stick dance, Dragon dance, folk songs and work songs are the famous representatives of traditional Bai dances and songs.

\subsection{The Opening of the Bai Culture Space}

Before the tourism development, living space of $\mathrm{W}$ town is relatively closed, it is a acquaintance society and its cultural life is conservative and xenophobic. After the tourism development, large number of investors and tourists poured into $\mathrm{W}$ town, these outsiders into the $\mathrm{W}$ Town People's living space, has brought their culture, impact and change the culture of the Bai culture. Initially, the relationship between the villagers and outsiders is more passive. As the government's protection of investors and tourists, the foreign investors are generally considered to be a strong side, allowing them to enter the cultural sites and cultural activities are a "had to do" choice. Along with the tourism industry has gradually become the main livelihood, people has brought considerable economic benefits. The Bai people began to take the initiative to get to know the people who brought them gold. In order to be able to engage in tourism reception and commodity trade, the Bai people are active in learning Chinese and foreign languages. Today, the vast majority of middle-aged Bai people and almost all of the young Bai people are fluent in Chinese, and some even fluent in English and Japanese. In order to better solve the tourism affairs (such as housing lease, travel services, business license, etc.) local people began to study the national laws and local regulations. More open management system replace the original management system that formed by the patriarchal clan system and the Local Rules. In order to obtain more economic benefits, local people started learning foreign hotel management mode; began to open cultural space such as ancestral temple, Confucian temple, the temple cultural sites; they take the initiative to change the harvest festivals, religious ceremonies, festivals into a big party, in order to meet the tastes of the tourists.

\section{Discussion}

\subsection{Minority Culture in the New Era Is a Culture Which Used to Be Re-Interpreted and Re-Constructed}

The tourism industry has a large scale to reshape the culture of minority nationalities; all the cultural characteristics that are suitable for the tourists' gaze are selected to participate in the cultural reconstruction. All the parts of the Bai culture, which will be amplified in the W Town, are highlighted; at the same time, all the features which are not related to the "special" will be masked or eliminated; the criterion of choice is the demand of tourists gaze and the preferences of the market. Therefore, the tourism culture is bound to be more "Bai" characteristic than the Bai culture. It will be a re-expression of the $\mathrm{W}$ town, and is a reconstruction of the Bai culture. This is the culture of the minority of our age; they are being re-imagined and reconstructed. On the surface, the traditional culture is to continue or even show, but by carefully looking, the truth is that tradition has been reinvention. "The culture of all ethnic minorities, never ceases to in the process of cultural reproduction, there is no 'pristine state”" (N. Q. Weng, 2006) [5]. Weng Naiqun's “cultural reproduction”, in the present context, is "cultural reconstruction". The "original ecology" of the tourism market is carefully selected and modeled according to modern aesthetic standards. When symbols and landscape are on display, they have already accessed a wide range of social recognition, and may even be curdled into new modes of culture, then become a re-invented tradition.

\subsection{The Process of Cultural Reconstruction Is a Process of the Weakening of Cultural Identity and the Growing of Cultural Awareness}

Tourism is a kind of medium, and the main culture, which is represented by the habits and preferences of tourist consumption, has a great influence on the measurement of minority, which influences the attitude of minority ethnic groups to its culture. Then the phenomenon of the weakening of cultural identity and the growing of cultural consciousness appeared. In W Town, the main performance is: first, the weakening of cultural identity. The cultural identity of the younger generation has been more severely impacted. Their recognition of foreign culture is strengthening; they give up the traditional moral ideas, believe money first, and pursue utilitarianism. The minority tourism development also lets the $\mathrm{W}$ town residents recognize the value of culture, and pay attention to 
the protection of the existing cultural traditions. Fei Xiaotong said: "People in a certain culture always have 'self-awareness', go to understand its origin, the formation process, the characteristics and development...” This is the first level of the concept of "cultural consciousness". "Self-awareness is to strengthen the ability to adapt to the new environment of the cultural transformation, the new era of cultural choice, the independent status" (X. T. Fei, 1988) [6]. This is the second level of the concept of "cultural consciousness". Minority should find the way of self transformation, and inspire the originality of ancient culture.

\section{References}

[1] Lin, Y.H. (1997) The General Theory of Ethnology. Central University for Nationalities Press, Beijing.

[2] Sun, J.X. (2011) Tourism in the Perspective of Anthropology and Sociology. Tourism Tribune, 11, 63.

[3] Guo, L. (2014) Research on Minority Tourism Development and the Space Production of Ethnic Culture. Journal of Southwest Minority University, 2, 7.

[4] Gui, R. (2013) On the Phenomenon of Symbolization of Minority Cultural Heritage. Research on Minority Nationality in Southwest Frontier, 14, 7.

[5] Weng, N.Q. (2001) The Eight Village beside the Nanning Kunming Railway. Ethnic Press of China, Beijing.

[6] Fei, X.T. (1988) Fei Xiaotong Academic Record. Beijing Normal University Press, Beijing. 